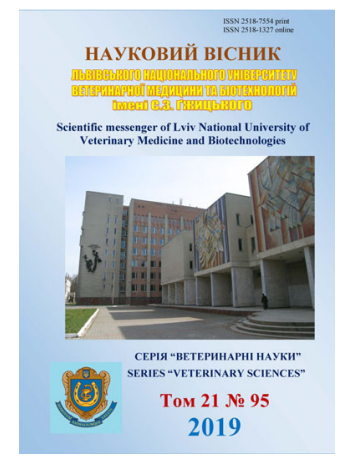

Науковий вісник Дьвівського національного університету ветеринарної медицини та біотехнологій імені С.З. Гжицького. Серія: Ветеринарні науки

Scientific Messenger of Lviv National University of Veterinary Medicine and Biotechnologies. Series: Veterinary sciences

UDC 619.615

\title{
Influence of the preparation "Bendamin" on the indicators of antioxidant protection of rat myocardium in experimental modeling of heart failure
}

\author{
I.S. Varkholiak, B.V. Gutyj \\ Stepan Gzhytskyi National University of Veterinary Medicine and Biotechnologies Lviv, Ukraine
}

Article info

Received 16.09.2019

Received in revised form 15.10.2019

Accepted 16.10.2019

Stepan Gzhytskyi National University of Veterinary Medicine and Biotechnologies Lviv, Pekarska Str., 50, Lviv, 79010, Ukraine.

Tel.: +38-096-486-26-85 E-mail:irynkavet@ukr.net
Varkholiak, I.S., \& Gutyj, B.V. (2019). Influence of the preparation "Bendamin" on the indicators of antioxidant protection of rat myocardium in experimental modeling of heart failure. Scientific Messenger of Lviv National University of Veterinary Medicine and Biotechnologies. Series: Veterinary sciences, 21(95), 98-101. doi: 10.32718/nvlvet9518

The aim of this study was to investigate the effect of Bendamin on the antioxidant status of rats in experimental doxorubicin-induced cardiomyopathy. The studies were performed on white sexually mature young male of Vistar line rats weighing 180-200 g, which were kept on a standard diet of the Institute Vivarium of the State Research Institute of Veterinary Drugs and Feed Additives. Animals were divided into 3 groups of 6 animals in each: control group - intact animals; experimental group R1, in which animals were simulated with doxorubicin-induced cardiomyopathy by intraperitoneal administration of doxorubicin at a dose of $2.5 \mathrm{mg} / \mathrm{kg} 3$ times a week for two weeks; experimental group R2, in which animals were injected with the drug "Bendamin" at a dose of $20 \mathrm{mg} / \mathrm{kg}$ after injection of doxorubicin. The data obtained indicate that the introduction into the experimental animals of the experimental group of doxorubicin is accompanied by intensification in the myocardium of the processes of free radical oxidation. The increase in diene conjugates was found to be $32.7 \%$ and TBK-active products increased by $37.6 \%$ compared to the control group of rats. Doxorubicin was also found to cause inhibition of the glutathione system of the animal's antioxidant protection after administration to rats. After administration of the drug "Bendamin", rats of the second experimental group were suppressed with lipid peroxidation under the conditions of doxorubicin intoxication. In the rats of the second experimental group, the level of intermediates and end products is likely to decrease, so in the rat myocardial homogenate the level of diene conjugates decreased by $16.8 \%$ and the level of TBA-active products by $20.8 \%$ compared to the first experimental group. who had clinical signs of cardiomyopathy caused by doxorubicin administration. The use of the drug "Bendamin" in rats of the second experimental group contributed to the enhancement of the enzymatic and non-enzymatic element of the antioxidant system, protecting the structural and functional integrity of cell bioembranes. The results of the studies enrich the pharmacological characteristics of the drug "Bendamin", indicate its sufficiently clear protective effect on the myocardium in experimental doxorubicin cardiomyopathy and is a convincing proof of the feasibility of the drug in veterinary practice.

Key words: pharmacology, preparation Bendamin, doxorubicin, rats, cardiovascular failure.

\section{Вплив препарату “Бендамін” на показники антиоксидантного захисту міккарду щурів за експериментального моделювання серцевої недостатності}

\author{
I.С. Вархоляк, Б.В. Гутий
}

Львівський національний університет ветеринарної медицини та біотехнологій імені С.3. Гжицького, м. Львів, Україна

Метою роботи було дослідити вплив препарату “Бендамін” на показники антиоксидантного статусу організму иурів за експериментальної доксорубіцин-індукованої кардіоміопатії. Дослідження проводили на білих статево-зрілих молодих шурах-самцях лінї Вістар масою тіла 180-200 г, яких утримували на стандартному раціоні інститутського віварію Державного науково- 
дослідного контрольного інституту ветеринарних препаратів та кормових добавок. Тварини були розподілені на 3 групи по 6 тварин у кожній: контрольна група - інтактні тварин; дослідна група Д1, в якій тваринам моделювали доксорубіцин-індуковану кардіоміопатію шляхом внутрішньочеревного введення доксорубіцину в дозі 2,5 мг/кг 3 рази на тиждень протягом двох тижнів; дослідна група Д2, в якій тваринам після ін 'єкиї доксорубічину, внутрішньошлунково вводили препарат “Бендамін” у дозі 20 мг/кг. Отримані дані вказують про те, щчо введення експериментальним тваринам дослідної групи доксорубіцину супроводжується інтенсифікацією в міокарді процесів вільнорадикального окиснення. Встановлено підвищення дієнових кон'югатів на $32,7 \%$ та ТБК-активних продуктів - на 37,6\% порівняно з контрольною групою шурів. Також встановлено, щзо доксорубіцин після введення в організм щурів зумовлює пригнічення активності глутатіонової системи антиоксидантного захисту організму тварин. Після застосування препарату “Бендамін” шурам другої дослідної групи встановлено пригнічення прочесів перекисного окиснення ліпідів за умов інтоксикації доксорубіцином. У щурів другої дослідної групи вірогідно знижується рівень проміжних та кіниевих продуктів, так у гомогенаті міокарда щурів другої дослідної групи рівень дієнових кон'югатів знизився на 16,8\%, а рівень ТБК-активних продуктів - на 20,8\% порівняно з першою дослідною групою, у яких були характерні клінічні ознаки кардіоміопатії, викликаної введенням доксорубіиину. Застосування препарату “Бендамін” шурам другої дослідної групи сприяло посиленню ензимної та неензимної ланки антиоксидантної системи, захищаючи структурно-функціональну цілісність біомембран клітин. Результати проведених досліджень збагачують фармакологічну характеристику препарату “Бендамін”, вказують його на достатньо виразний захисний вплив на міокард за експериментальної доксорубіцинової кардіоміопатії та є переконливим доведенням доцільності застосування препарату у ветеринарній практиці.

Ключові слова: фармакологія, препарат “Бендамін”, доксорубіциин, щурі, серцево-судинна недостатність.

Вступ

Патології серця і судин у собак та кішок надзвичайно різноманітні та достатньо поширені у щоденній практиці ветеринарного лікаря в Україні та за іiі межами. Згідно класифікації професора Г.В. Домрачева, у домашніх тварин серцево-судинна патологія поділяється на хвороби міокарда, перикарда, ендокарда та хвороби кровоносних судин. Існує тісна взаємозалежність між вище вказаними патологіями, віком та породами тварин (Undhad et al., 2012; Varkholiak, 2016; Zhulikova, 2016; Yata et al., 2019).

Серцева недостатність у собак може бути як вродженим дефектом, так і набутим у результаті перенесення інфекції. Дана патологія трапляється переважно у собак похилого віку. При серцевій недостатності у собак серце не спроможне повноцінно виконувати свої фізіологічні функції і забезпечувати організм нормальним кровообігом. Відповідно це спонукає до виникнення застійних явищ та погіршенню кровопостачання органів, що своєю чергою призводить до появи патологічних змін у міокарді (Tjostheim et al., 2019; Oldach et al., 2019). Зважаючи на аналіз даних вітчизняних і зарубіжних дослідників розробка зручного у застосуванні і безпечного комплексного кардіологічного препарату, використання якого дозволить підвищити ефективність лікування тварин і широкого спектру серцево-судинних патологій є на часі і становить актуальність проведення досліджень для ветеринарної медицини (Varkholiak \& Gutyj, 2018; 2019; Varcholyak \& Gutyi, 2019).

Метою роботи було дослідити вплив препарату "Бендамін" на показники антиоксидантного захисту міокарду щурів за експериментального моделювання серцевої недостатності.

\section{Матеріал і методи досліджень}

Дослідження проводили на білих статево-зрілих молодих щурах-самцях лінії Вістар масою тіла 180200 г, яких утримували на стандартному раціоні інститутського віварію Державного науково-дослідного контрольного інституту ветеринарних препаратів та кормових добавок. Протягом усього експерименту щурів утримували на збалансованому раціоні, що містив усі необхідні компоненти, питну воду тварини отримували без обмежень із скляних поїлок об'ємом 0,2 літра.

Експериментальні дослідження проведені у відповідності до вимог лікарсько-біологічного експерименту 3 підбору аналогів, постановці контролю, дотриманню однакових умов годівлі та утримання під час проведення досліду та обліку результатів.

Для створення моделі доксорубіцин-індукованої кардіоміопатії було відібрано 24 щурів-самців. Тварини були розподілені на 3 групи по 6 тварин у кожній: контрольна група - інтактні тварин; дослідна група Д1, в якій тваринам моделювали доксорубіциніндуковану кардіоміопатію шляхом внутрішньочеревного введення доксорубіцину в дозі 2,5 мг/кг 3 рази на тиждень протягом двох тижнів; дослідна група Д2, в якій тваринам після ін'єкції доксорубіцину, внутрішньошлунково вводили препарат "Бендамін” у дозі $20 \mathrm{Mг} / \mathrm{к}$.

Уміст продуктів ПОЛ - дієнових кон'югатів та ТБК-активних продуктів, активність антиоксидантних ензимів - глутатіонпероксидази та глутатіонредуктази, а також рівень відновленого глутатіону визначали за методами (Vlizlo et al., 2012).

Усі маніпуляції з тваринами проводили відповідно до Свропейської конвенції про захист хребетних тварин, які використовуються для експериментальних i наукових цілей (Страсбург, 1986 р.).

Аналіз результатів досліджень проводили за допомогою пакету програм Statistica 6.0. Вірогідність різниць оцінювали за t-критерієм Стьюдента. Результати вважали вірогідними при $\mathrm{P} \leq 0,05$.

\section{Результати та їх обговорення}

Отримані дані вказують про те, що введення експериментальним тваринам дослідної групи доксорубіцину супроводжується інтенсифікацією в міокарді процесів вільнорадикального окиснення. Так, на основі проведених досліджень встановлено підвищення проміжних та кінцевих продуктів ПОЛ, а саме 
встановлено підвищення дієнових кон'югатів на $32,7 \%$ та ТБК-активних продуктів - на 37,6\% порівняно 3 контрольною групою щурів (табл. 1). Окиснювальне пошкодження білків призводить до порушення метаболізму кардіоміоцитів. Так, в умовах інтенсифікації вільнорадикального окиснення вільні радикали пригнічують ензимну ланку антиоксидантної системи, підсилюючи таким чином явища оксидаційного стресу в міокарді (Martyshuk \& Gutyj, 2019). Негативний ефект окиснювально-модифікованих білків у клітині, очевидно пов'язаний з тим, що окиснені білки виступають як джерело вільних радикалів, які виснажують запаси клітинних антиоксидантів.

Збільшення кількості ТБК-активних продуктів в міокарді щурів під впливом доксорубіцину вказує про збіднення міокарду поліненасиченими жирними кислотами, які є основним субстратом перекисного окиснення ліпідів. Міокард втрачає основне джерело синтезу простагландинів, що необхідні для його нормальної діяльності та відіграють важливу роль у процесах адаптації міокарду до навантаження.

\section{Таблиця 1}

Показники інтенсивності перекисного окиснення ліпідів у гомогенаті міокарду щурів за експериментального моделювання серцевої недостатності та дії препарату “Бендамін” (M \pm m, n =6)

\begin{tabular}{lrrc}
\hline \multicolumn{1}{c}{ Показники } & \multicolumn{3}{c}{ Групи тварин } \\
\cline { 2 - 4 } & Контрольна & \multicolumn{1}{c}{ Дослідна 1 } & \multicolumn{1}{c}{ Дослідна 2 } \\
\hline Дієнові кон'югати, мкмоль/Г & $6,45 \pm 0,13$ & $8,56 \pm 0,39 *$ & $7,12 \pm 0,22 *$ \\
ТБК-активні продукти, ммоль/г & $30,79 \pm 4,50$ & $42,36 \pm 2,11^{*}$ & $33,57 \pm 2,47$ \\
\hline
\end{tabular}

Після застосування препарату “Бендамін” щурам другої дослідної групи встановлено пригнічення процесів перекисного окиснення ліпідів за умов інтоксикації доксорубіцином. У щурів другої дослідної групи вірогідно знижується рівень проміжних та кінцевих продуктів, так у гомогенаті міокарда щурів другої дослідної групи рівень дієнових кон'югатів знизився на 16,8\%, а рівень ТБК-активних продуктів - на 20,8\% порівняно з першою дослідною групою, у яких були характерні клінічні ознаки кардіоміопатії, викликаної введенням доксорубіцину.

Отже, препарат "Бендамін" гальмує надмірне утворення продуктів ПОЛ у патологічно змінених тканинах серця щурів, проявляє індукуючий вплив на систему антиоксидантного захисту, таким чином захищає структурно-функціональну цілісність біомембран клітин.

Проведеними дослідженнями встановлено, що доксорубіцин зумовлює пригнічення активності глутатіонової системи антиоксидантного захисту організму щурів у першій дослідній групі. Так, рівень відновленого глутатіону у гомогенаті міокарду щурів першої дослідної групи вірогідно знижувався на 45,3\%, тоді як активність глутатіонреоксидази та глутатіонредуктази відповідно знизилася на 26,1 і 33,3\% порівняно 3 показниками контрольної групи щурів (табл. 2).

\section{Таблиця 2}

Показники системи антиоксидантного захисту у гомогенаті міокарду щурів за експериментального моделювання серцевої недостатності та дії препарату “Бендамін” (M \pm m, n =6)

\begin{tabular}{lccc}
\hline \multicolumn{1}{c}{ Показники } & \multicolumn{3}{c}{ Групи тварин } \\
\cline { 2 - 4 } & Контрольна & Дослідна 1 & Дослідна 2 \\
\hline Відновлений глутатіон, мкмоль/Г & $0,53 \pm 0,08$ & $0,29 \pm 0,05^{*}$ & $0,39 \pm 0,05^{*}$ \\
Глутатіонпероксидаза, нмоль $/$ хв $\times$ мг протеїну & $6,81 \pm 0,79$ & $5,03 \pm 0,54^{*}$ & $6,37 \pm 0,37$ \\
Глутатіонредуктаза, мкмоль/хв $\times$ мг протеїну & $0,57 \pm 0,11$ & $0,38 \pm 0,12^{*}$ & $0,51 \pm 0,10$ \\
\hline
\end{tabular}

Застосування препарату “Бендамін” щурам другої дослідної групи за умов доксорубіцинової кардіоміопатії сприяло активації глутатіонової ланки антиоксидантної системи в міокарді дослідних щурів. Встановлено, що рівень відновленого гутатіону у гомогенаті міокарду другої дослідної групи коливався у межах $0,39 \pm 0,05$ мкмоль/г.

Після дослідження активності глутатіонпероксидази у міокарді щурів дослідних груп встановлено, що найвищою вона була у другої дослідної групи щурів, яким задавали препарат “Бендамін”. Активність даного ензиму відповідно була вищою на 26,6\% відносно інтоксикованих щурів, яких не лікували.

Активність глутатіонредуктази також була вищою у другої дослідної групи, де відповідно становила $0,51 \pm 0,10$ мкмоль/хв × мг протеїну, тоді як у першої дослідної груп даний показник становив $0,38 \pm 0,12$ мкмоль $/$ хв $\times$ мг протеїну.

Отже, на основі проведених досліджень впливу препарату "Бендамін" на показники антиоксидантної системи міокарду дослідних щурів за умов доксорубіцинової інтоксикації, встановлено що новостворений препарат проявляє корегувальну дію в умовах окисного стресу, притаманного доксорубіцин-індукованій кардіоміопатії у щурів. Результати проведених досліджень збагачують фармакологічну характеристику препарату “Бендамін”, вказують його на достатньо виразний захисний вплив на міокард за експериментальної доксорубіцинової кардіоміопатії та є переконливим доведенням доцільності застосування препарату у ветеринарній практиці. 


\section{Висновки}

Дія доксорубіцину та розвиток гіпоксичного стану у щурів супроводжуються активацією окисного стресу та посиленням вільнорадикальних процесів, на що вказує підвищений рівень проміжних та кінцевих продуктів перекисного окиснення ліпідів, а також пригнічення активності системи антиоксидантного захисту.

Застосування препарату “Бендамін” щурам другої дослідної групи сприяло посиленню ензимної та неензимної ланки антиоксидантної системи, захищаючи структурно-функціональну цілісність біомембран клітин.

Препарат "Бендамін” гальмує надмірне утворення продуктів ПОЛ у патологічно змінених тканинах серця щурів.

\section{References}

Martyshuk, T.V., \& Gutyj, B.V. (2019). Influence of feed additive "Butaselmevit-Plus" on antioxidant status of rats in conditions of oxidative stress. Scientific Messenger of Lviv National University of Veterinary Medicine and Biotechnologies. Series: Agricultural sciences, 21(90), 76-81. doi: 10.32718/nvlvet-a9013.

Oldach, M.S., Ueda, Y., Ontiveros, E.S., Fousse, S.L., Harris, S.P., \& Stern, J.A. (2019). Cardiac Effects of a Single Dose of Pimobendan in Cats With Hypertrophic Cardiomyopathy; A Randomized, Placebo-Controlled, Crossover Study. Front Vet Sci., 6, 15. doi: 10.3389/fvets.2019.00015.

Tjostheim, S.S., Kellihan, H.B., Grint, K.A., \& Stepien, R.L. (2019). Effect of sildenafil and pimobendan on intracardiac heartworm infections in four dogs. $J$ Vet Cardiol., 23, 96-103. doi: 10.1016/j.jvc.2019.02.001.

Undhad, V.V., Fefar, D.T., Jivani, B.M., Gupta, H., Ghodasara, D.J., Joshi, B.P. \& Prajapati, K.S. (2012). Cardiac troponin: an emerging cardiac biomarker in animal health. Vet. World, 5, 508-511. doi: 10.5455/vetworld.2012.508-511.

Varcholyak, I.S., \& Gutyi, B.V. (2019). Determination of the chronic toxicity of preparation "Bendamin" on laboratory animals. Theoretical and Applied Veterinary Medicine, 7(2), 63-68. doi: 10.32819/2019.71011.

Varkholiak, I.S. (2016). The usage of medicines at the cardiovascular pathologies in dogs and cats. Scientific Messenger LNUVMBT named after S.Z. Gzhytskyj, 18, 3(71), 261-265. https://nvlvet.com.ua/index.php/ journal/article/view/974.

Varkholiak, I.S., \& Gutyj, B.V. (2018). Determination of acute toxicity of "Bendamin" drug in laboratory animals. Scientific Messenger of Lviv National University of Veterinary Medicine and Biotechnologies, 20(92), 209-212. doi: 10.32718/nvlvet9243.

Varkholiak, I.S., \& Gutyj, B.V. (2019). The degree of cumulation of the "Bendamin" drug in the body of white rats. Scientific Messenger of Lviv National University of Veterinary Medicine and Biotechnologies. Series: Veterinary sciences, 21(94), 82-85. doi: 10.32718/nvlvet9415.

Vlizlo, V.V., Fedoruk, R.S., \& Raty`ch, I.B. (2012). Laboratorni metody' doslidzhen' u biologiyi, tvary`nny`cztvi ta vetery`narnij medy`cy`ni: dovidny`k. L`viv: Spolom (in Ukrainian).

Yata, M., Kooistra, H.S., \& Beijerink, N.J. (2019). Cardiorenal and endocrine effects of synthetic canine BNP1-32 in dogs with compensated congestive heart failure caused by myxomatous .mitral valve disease. J Vet Intern Med., 33(2), 462-470. doi: 10.1111/jvim.15416.

Zhulikova, O.A. (2016). Monitoring rasprostranenija serdechno-sosudistyh zabolevanij sredi koshek i sobak v g. Blagoveshhensk amurskoj oblasti. Dal'nevostochnyj agrarnyj vestnik, 2(38), 49-56. https://cyberleninka.ru/article/n/monitoringrasprostraneniya-serdechno-sosudistyh-zabolevaniysredi-koshek-i-sobak-v-g-blagoveschensk-amurskoyoblasti (in Russian). 